3. Методика государственного сортоиспытания сельскохозяйственных культур. М.Колос. 1985. $269 \mathrm{c}$.

4. Сорокин О.Д. Прикладная статистика на компьютере. Новосибирск: ГУПРПО CO PACXH. 2004.162 c.

DOI 10.18699/GPB2020-115

\title{
Исходный материал для селекции озимой пшеницы в Удмуртской Республике
}

Торбина И.В. к.с.-х.н., с.н.С.

Удмуртский НИИСХ - филиал ФГБУН «Удмуртский федеральный исследовательский центр Уральского отделения Российской академии наук» (УдмФИЦУрО РАН); Ижевск, Россия.

e-mail:torbinaiv@udman.ru

Целью данных исследований явилось изучение набора образиов озимой пшенииы из Коллекиии генетических ресурсов растений ВИР по комплексу хозяйственно-ценных признаков и выделение наиболее адаптивных сортов для условий Удмуртской Республики. Значительное колебание урожайности озимой пшеницы по годам предопределяет важность селекции в регионе на повышение устойчивости генотипов к неблагоприятным биотическим и абиотическим факторам среды. Показатель уровня и стабильности изучаемых сортов (ПУСС) коллекционного питомника по урожайности определяли по методике Э.Д. Неттевича (1985). Выявлены сорта, в среднем за 2016 и 2017 г2., обеспечившие урожайность 310-395 г/м², прибавка ихк стандарту Московская 39 составила 11-42\%. Это сорта STH-346 (Польша), Lyubava odes'ka, Ukrainka odes'ka, Tsyghanka (Украина), Sjuita, Uzljot, Fantazija, Ehlegija (Белоруссия). Показатель уровня стабильности (ПУСС) отмеченных сортообразиов составил 121-533\% к стандарту.

Ключевые слова: озимая пшеница, коллекиия генетических ресурсов растений ВИР, селекция, стабильность урожайности, хозяйственно-ценные признаки.

\section{Source material for winter wheat breeding in the Udmurt Republic}

Torbina I.V., Udmurt Rechearch Institute of Agriculture branch of Udmurt Federal rechearch center of the Ural office of the RAS; Izhevsk, Russia.

The purpose of these studies was to study a set of samples of winter wheat from the Collection of plant genetic resources (VIR) on a complex of economically valuable traits and to identify the most adaptive material to grow in the conditions 
of the Udmurt Republic. A significant variation in winter wheat yield over the years determines the importance of breeding in the region to increase the resistance of genotypes to adverse biotic and abiotic environmental factors. The indicator of the level and stability of the studied varieties (PUSS) of the collection nursery was determined by the method of E. D. Nettevich (1985). Identified varieties that on average in 2016 and 2017 provided a yield of 310-395 $\mathrm{g} / \mathrm{m}^{2}$, their increase to the Moscow 39 standard was 11-42\%. These are varieties STH-346 (Poland), Lyubava odes'ka, Ukrainka odes'ka, Tsyghanka (Ukraine), Sjuita, Uzljot, Fantazija, Ehlegija (Belarus). The indicator of the stability level (PUSS) of the noted samples was 121-533\% of the standard.

Keywords: winter wheat, collection of plant genetic resources (VIR), breeding, yield stability, economic valuable characteristics.

Озимая пшеница принадлежит к числу наиболее ценных и высокоурожайных, но требовательных к условиям возделывания культур. В структуре посевных площадей Удмуртской Республики доля озимой пшеницы была незначительна, в 2005-2018 гг. колебалась от 0,2 до 2,1 \%, а площадь посева от 1,8 до 24,5 тыс.га [3]. Значительное колебание урожайности озимой пшеницы по годам [2] предопределяет адаптивную направленность селекции в регионе. Базой исходного материала для решениязадач селекции в Удмуртском НИИСХ служит Коллекция генетических ресурсов растений ВИР.

Цель исследований - изучить по комплексу хозяйственно-ценных признаков набор образцов, пополнивших в последние годы коллекцию озимой мягкой пшеницы, и выявить наиболее ценные образцы для селекции культуры в Удмуртской Республике.

Изучение 46 образцов озимой пшеницы проводили в 2015-2016 и 2016-2017 гг. Посевы располагали на опытном поле института. Закладку полевых опытов, наблюдения и учеты проводили согласно Методике государственного сортоиспытания (1989) и методическим указаниям «Пополнение, сохранение в живом виде и изучение мировой коллекции пшеницы, эгилопса и тритикале» (1999). Посев осуществляли на делянках площадью $1,0 \mathrm{~m}^{2}$ по занятому (клевер, однолетние травы) пару в первой декаде сентября сеялкой CP-1. Норма высева 4 млн. шт. всхожих семян на 1 га. Убирали образцы по мере созревания вручную. Почва опытного участка хорошо окультуренная дерново-подзолистая среднесуглинистая, слабокислая, со средним содержанием гумуса, очень высоким содержанием подвижного фосфора, высоким обменного калия. Существенность разницы полученных данных между вариантами опытов устанавливали по t-критерию [4]. Показатель уровня и стабильности урожайности сорта получали умножением средней урожайности сорта, выраженной в \% к стандарту, на индекс стабильности. ПУСС сорта выражали в \% к стандарту. Индекс стабильности рассчитывали путем деления средней урожайности сорта в ц/га на коэффициент вариации урожайности [1]. 
Метеорологические условия в годы проведения исследований отличались условиями перезимовки. Теплая, с частыми оттепелями зима 20152016 гг. привела к значительному изреживанию посевов. Перезимовка сортов была очень низкой (0-10\%, у стандарта - $6 \%$ ). Однако ранний сход снега с полей (10 апреля), теплый и дождливый апрель, теплый май способствовали отрастанию растений и интенсивному весеннему кущению. Формирование и налив зерна проходили в условиях достаточного увлажнения (июнь ГТК 1,4). В 2016-2017 сельскохозяйственном году зима была довольно холодной и многоснежной, а лето - прохладное и влажное. Перезимовка сортов колебалась от 40 до 80 \%, у стандарта Московская 39 была высокой $(73 \%)$.

В среднем за 2016 и 2017 гг. урожайность сортообразцов озимой пше-

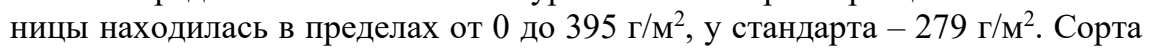
STH-346 (Польша), Lyubava odes'ka, Ukrainka odes'ka, Tsyghanka (Украина), Sjuita, Uzljot, Fantazija, Ehlegija (Белоруссия) сформировали урожайность 310-395 г/м², обеспечив прибавку к стандарту 11-42 \% (таблица). Данные сорта показали и более высокую, чем у стандарта, стабильность урожайности. Показатель уровня стабильности (ПУСС) отмеченных сортообразцов составил $121-533 \%$ к стандарту.

Перезимовка сортообразцов находилась в пределах от 22 до $45 \%$, у стандарта - 40 \%. Варьирование перезимовки по годам значительное (коэффициент вариации от 42 до $71 \%$ ). Перезимовку на уровне или несколько выше стандарта показали сорта Uzljot (45 \%), STH-346 (42,5 \%), а также украинские сорта Kyivs'kaostista (40\%) и Nikoniya (40 \%).

В среднем за годы исследований высокой продуктивной кустистостью (5,7-6,2 стебля на растение) обладали сорта STH-796 (Польша) и Culver (США), у стандарта Московская 39 - 4,1 стебля на растение. Слабой вариабельностью показателя характеризовался сорт Culver (V=10 \%).

Масса 1000 зерен сортов коллекции находилась в пределах от 21,4 до 47,1 г, у стандарта Московская 39 - 42,3 г. Крупное зерно (масса 1000 зерен 44,8-47,1 г) имели девять сортов, среди них - STH-346, Lyubavaodes'ka и белорусские сорта Navina, Sjuita и Uzljot. Изменчивость показателя слабая и средняя (коэффициент вариации 2-13\%).

Высокая озерненность колоса (38,5-59,7 шт.) была у 16 сортообразцов коллекции. Варьирование признака слабое ( $\mathrm{V}=2$ и 9 \%) у сортов Tsyghanka (Украина) и Uzljot; среднее (V=12-19 \%) - STH-346, Ukrainkaodes'ka и Sjuita; сильное (V=31\%) - Fantazija. Данный показатель стандарта Московская 39 составил 35,1 шт. 
Таблища - Урожайность и стабильность выделившихся образцов озимой пшеницы коллекции ВИР (2016, 2017 гг.)

\begin{tabular}{|c|c|c|c|c|c|c|c|}
\hline \multirow{2}{*}{ 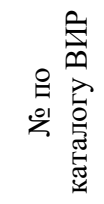 } & \multirow{2}{*}{ Сорт } & \multicolumn{3}{|c|}{ Урожайность, г/м² } & \multirow{2}{*}{ 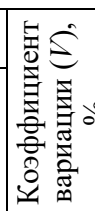 } & \multirow{2}{*}{ 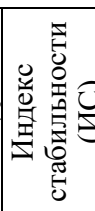 } & \multirow{2}{*}{ 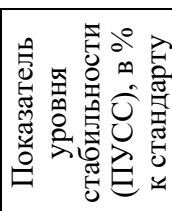 } \\
\hline & & 2016 г. & 2017 г. & средняя & & & \\
\hline 64160 & $\begin{array}{l}\text { Московская } 39 \text { - } \\
\text { стандарт }\end{array}$ & 111 & 446 & 279 & 85 & 3,3 & 100 \\
\hline 65620 & STH-346 & 202 & 506 & 354 & 61 & 5,8 & 223 \\
\hline 65628 & Lyubava odes'ka & 121 & 500 & 310 & 86 & 3,6 & 121 \\
\hline 65629 & Nakhodka 4 & 193 & 349 & 271 & 41 & 6,6 & 194 \\
\hline 65634 & Ukrainka odes'ka & 136 & 548 & 342 & 85 & 4,0 & 149 \\
\hline 65639 & Tsyghanka & 224 & 448 & 336 & 47 & 7,1 & 258 \\
\hline 65648 & Sjuita & 115 & 643 & 379 & 98 & 3,9 & 161 \\
\hline 65650 & Uzljot & 139 & 651 & 395 & 92 & 4,3 & 185 \\
\hline 65651 & Fantazija & 284 & 400 & 342 & 24 & 14,3 & 533 \\
\hline 65652 & Ehlegija & 171 & 496 & 334 & 69 & 4,8 & 175 \\
\hline $\begin{array}{l}\text { Доверит } \\
\text { Для сред } \\
\text { стандар }\end{array}$ & $\begin{array}{l}\text { ельный интервал } \\
\text { него значения }\end{array}$ & $73 \div 150$ & $338 \div 555$ & & & & \\
\hline
\end{tabular}

В 2017 г. изучали пораженность растений болезнями выпревания. Распространенность снежной плесени доходила до 40 \% (сорт Sjuita), склеротиниозом - до 60 \% у линии KS92WGRC23 (США), у стандарта Московская 39 соответственно 8 и $22 \%$. Значительно более высокой, чем у стандарта, устойчивости сортов коллекции к болезням выпревания не обнаружено.

Высокоустойчивыми к бурой ржавчине в естественных полевых условиях были сорта STH-346, Sjuita, Uzljot, Ehlegija, Culver, др. Стандарт Mocковская 39 характеризовался средней устойчивостью к бурой ржавчине $(4,8$ балла).

Корреляционный анализ данных в среднем за 2016-2017 гг. выявил сильную положительную зависимость урожайности от густоты продуктивного стеблестоя $(\mathrm{r}=0,90)$ и перезимовки $(\mathrm{r}=0,82)$, слабую положительную - с числом зерен в колосе $(\mathrm{r}=0,13)$, слабую отрицательную - с продуктивной кустистостью (r=-0,09), среднюю отрицательную - с массой 1000 зерен $(\mathrm{r}=-0,40)$.

Таким образом, изучение коллекции ВИР позволило выделить ценные по ряду хозяйственно-полезных признаков образцы-источники, которые можно вовлекать в селекцию озимой пшеницы в условиях Удмуртской Республики.

Благодарности: работа выполнена в рамках договора о научном со- 
трудничестве между Удмуртским НИИСХ - филиалом ФГБУН «Удмуртский федеральный исследовательский центр Уральского отделения Российской академии наук" и ФГБНУ «Федеральный исследовательский центр Всероссийский институт генетических ресурсов растений» (ВИР) с использованием уникальной научной установки «Коллекция генетических ресурсов растений ВИР». За подбор материала для исследований и информацию о нем выражаю благодарность к.б.н., в.н.с. ВИР А.Г. Хакимовой.

\section{Списоклитературь}

1. Неттевич, Э.Д. Повышение эффективности отбора яровой пшеницы на стабильность урожайности и качество зерна / Э.Д. Неттевич, А.И. Моргунов, М.И. Максименко // Вестник сельскохозяйственной науки. - 1985. - №1. - С. 66-74.

2. Озимые зерновые культуры в Удмуртской Республике: монография / Н.Г. Туктарова, А.Г. Курылева, С.С. Жирных, И.В. Торбина; под науч. ред. А.В. Леднева; ФГБНУ Удмуртский НИИСХ. - Ижевск: ООО ПКФ «Буква», 2017. - 124 с.

3. Посевные площади сельскохозяйственных культур. https://fedstat.ru/indicator/31328 (дата обращения 27.02.20).

Торбина, И.В. К методике анализа селекционных образцов в ранних звеньях селекционного процесса / И.В. Торбина // Известия Великолукской государственной сельскохозяйственной академии. - 2017. - № 3. - с. 23-27.

DOI 10.18699/GPB2020-116

\section{Урожайность и адаптивность сортов яровой тритикале в Нечерноземной зоне РФ}

Тысленко А.М.*, к.с.-х.н., в.н.с.; Зуев Д.В., н.с.; Скатова С.Е., к.с.-х.н., заведуюшая лабораторией.

ФГБНУ «Верхневолжский ФАНЦ», г. Суздаль, Россия.

*e-mail:tslo@bk.ru

В 2015-2018 г2. проведена оценка урожайности и адаптивности 6 сортов яровой тритикале селекции ФГБНУ «Верхневолжский ФАНЦ» на легкой дерново-подзолистой и серой лесной почвах. Наибольшая продуктивность испытуемых сортов отмечалась на серой лесной почве и достигала у сорта Доброе 8,5 m/zа. На дерново-подзолистой почве максимальная урожайность данного сорта не превышала $5,6 \mathrm{~m} / 2$. Не зависимо от почвенного покрова урожайность сортов яровой тритикале сильно варьировала по годам (коэффициент вариации от 20,7 до 34,2%). Наибольиим показателем «реализации потенциальной урожайности» характеризовались сорта Норманн, Аморе, Доброе на серой лесной почве (более $70 \%$ ); на супесчаной дерново-подзолистой - у всех изучаемых сортов даннылй показатель превышал $70 \%$. 